\title{
A review on medicinal plant extracts and their active ingredients against methicillin-resistant and methicillin- sensitive Staphylococcus aureus
}

\author{
Marzieh Askarinia ${ }^{1,2}$, Ali Ganji ${ }^{3,4}$, Farhad Jadidi-Niaragh ${ }^{5,6,7}$, Sajad Hasanzadeh ${ }^{8}$, Bahram Mohammadi ${ }^{2}$, Farideh \\ Ghalamfarsa $^{2}$, Ghasem Ghalamfarsa ${ }^{2 *}$, Hassan Mahmoudi ${ }^{*}$ \\ ${ }^{1}$ Student Research Committee, Yasuj University of medical sciences, Yasuj, Iran \\ ${ }^{2}$ Medicinal Plants Research Center, Yasuj University of Medical Sciences, Yasuj, Iran \\ ${ }^{3}$ Molecular and Medicine Research Center, Arak University of Medical Sciences, Arak, Iran \\ ${ }^{4}$ Department of Microbiology and Immunology, School of Medicine, Arak University of Medical Sciences, Arak, Iran \\ ${ }^{5}$ Immunology Research Center, Tabriz University of Medical Sciences, Tabriz, Iran \\ ${ }^{6}$ Department of Immunology, Faculty of Medicine, Tabriz University of Medical Sciences, Tabriz, Iran \\ ${ }^{7}$ Department of Immunology, Faculty of Medicine, Tehran University of Medical Sciences, Tehran, Iran \\ ${ }^{8}$ Department of Internal Medicine, Yasouj University of Medical Sciences, Yasouj, Iran \\ ${ }^{9}$ Department of Microbiology, Faculty of Medicine, Hamadan University of Medical Sciences, Hamadan, Iran
}

\section{A R T I C L E I N F O}

\section{Article Type:}

Review

\section{Article History:}

Received: 17 January 2019

Accepted: 9 March 2019

\section{Keywords:}

$\beta$-lactam antibiotic

Staphylococcus aureus

Medicinal plants

MRSA, MSSA

Methicillin-resistant

\begin{abstract}
A B S T R A C T
Staphylococcus aureus is among the pathogens capable of developing a broad spectrum of infections in human beings. In addition to the hospital, the bacterium is present in the community and has a high resistance to antibiotics, which is also increasing on an ongoing basis. Resistance to $\beta$-lactam antibiotic family is one of the concerns about the bacterium that has encountered the treatment of such infections with difficulty. Due to the increased resistance and importance of this bacterium, new strategies are needed to control this pathogen. One of these approaches is the use of medicinal plants, which has attracted many researchers in the last decade. Several studies have been carried out or are being designed using various herbs to find active ingredients to deal with this bacterium. The aim of this study was to present the antibacterial activity of different medicinal plants and the effects of their active ingredients on methicillin-resistant and methicillin-sensitive S. aureus (MRSA, MSSA), and to clarify the pathway to further studies in this regard.
\end{abstract}

Implication for health policy/practice/research/medical education:

Due to the increased resistance and importance of this bacterium, new strategies are needed to control this pathogen. One of these approaches is the use of medicinal plants, which has attracted many researchers in the last decade.

Please cite this paper as: Askarinia M, Ganji A, Jadidi-Niaragh F, Hasanzadeh S, Bahram Mohammadi B, et al. A review on medicinal plant extracts and their active ingredients against methicillin-resistant and methicillin-sensitive Staphylococcus aureus. J Herbmed Pharmacol. 2019;8(3):173-184. doi: 10.15171/jhp.2019.27.

\section{Introduction}

Staphylococcus aureus is a gram-positive bacterium colonized on the skin, and present in the nose of $25 \%$ to $30 \%$ of healthy people (1). In general, the nose, armpit and groin before the invasive infection with $S$. aureus are sites where the bacteria are colonized (2). A broad spectrum of infections, ranging from minor skin infections to postoperative wound infections are caused by $S$. aureus (3). This bacterium is one of leading human pathogens that has high resistance to antibiotics and is the main source of hospital-acquired and community-acquired infections $(4,5)$. Nosocomial infections with $S$. aureus, in particular methicillin-resistant $S$. aureus (MRSA), are of the major causes of hospitalization, which imposes a high economic burden on the patients and the hospital (6). The MRSA is one of the opportunistic pathogens considered to be a serious threat to public health (7). The bacterium was described for the medical community through a prominent article published for the first time in a British Medical Journal (8). After the introduction of

*Corresponding authors: Ghasem Ghalamfarsa, Tel: +98-9177746921, Email: Ghasem_Ghalamfarsa@yahoo.com; Hassan Mahmoudi, Tel: +989189539458, Hassanmahmoudi24@gmail.com 
methicillin to the medical arena in 1960, the MRSA was first identified in Europe. Natural resistant strains have been isolated without the use of methicillin or related agents in some countries (9). Methicillin resistance occurs due to the presence of the mecA gene encoding PBP2a (penicillin-binding protein $2 \mathrm{a}$ ) molecule that has a slight affinity for binding to $\beta$-lactam antibiotics. The PBPs are trans-peptidases that catalyze the interaction between the peptide bridges of the bacterial cell wall. The mutation in this molecule causes antibiotic resistance of the bacterium (10).

A similar PBP2a has been described recently, encoding by mecC, and is homogeneous by $70 \%$ with mecA (11). The SCC (Staphylococcal cassette chromosomes) elements have been so far described as the only carrier for the mecA gene. These elements are classified into different types according to the type of recombinases they carry and their overall genetic composition. Coagulase-negative staphylococci with mecA are of the potential reservoir of these elements (12). The first strain of community-acquired MRSA (CA-MRSA) was reported in 1990. In recent years, it has been unclear the distribution of hospital-acquired MRSA (HA-MRSA) and CA-MRSA strains. Both strains are endemic in hospitals in many areas. The changes in the MRSA evolution have made these bacteria a serious threat to public health. The CA-MRSA develops a series of skin and soft tissue infections and sometimes severe infections (3,13-14). Indiscriminate administration of antibiotics is one of the causes of antibiotic resistance. The high level of antibiotic resistance and the presence of SCC mec types indicate that infections caused by these strains require more advanced care and also newer antibiotics (15). The antibiotic resistance is the biggest challenge for the medical area in the treatment of infectious diseases. The resistance has been documented not only against natural and semi-synthetic antibiotics, but also against fully synthesized compounds (such as fluoroquinolones) or antibiotics that do not even penetrate through the cells (such as vancomycin) (16). This study was aimed to review the antibacterial activity of different medicinal plants and the effects of their active ingredients on MRSA and MSSA, and to clarify the pathway to further studies in this regard.

\section{Medicinal plants}

Herbal medicines embrace a wide range of practices and therapies outside the realm of traditional Western medicine. Although herbal medicines are not risk free, they can still be safer than synthetic drugs. The potential benefits of herbal medicines include high acceptance by patients, effectiveness, relative safety and relatively low costs (17). Due to the increasing use of herbal medicines around the world, their safety has often become a medical issue (18). Many consumers are demanding food that is free of harmful and chemically synthetic materials, including food antimicrobial preservatives. As a result, the passion for natural antimicrobial substances has been increased as potential alternative to commonly used antimicrobial agents to increase half-life and control the food pathogens (19). The complementary and alternative medicine practices are increasingly being employed to detect or treat allergic diseases, and numerous studies have been reported on the benefits of this type of medication (20). Conventional drugs usually provide antibiotic treatment for bacterial infections, but the problem of increasing antibiotic resistance reveals the need for new therapies. Over the past few years, the use of natural ingredients has attracted further attention to promote human and animal health. Hence, increased antibiotic resistance has encouraged healthcare providers to be in the wake of alternatives, including botanical and herbal medicines to manage the invasive microorganisms $(21,22)$.

Huge consideration has been directed to determine the antimicrobial activity of the plant extracts in traditional medicine, essential oils or other isolated ingredients, such as alkaloids, flavonoids, diterpenes, triterpenes or naphthoquinones, sesquiterpene lactones, and the like. Some of these compounds have been separated after detecting the antimicrobial activity of the plant (23). The flavonoids are compounds present in photosynthetic cells and commonly found in fruits, vegetables, stems, seeds, flowers, and so on. Many studies have been conducted to identify the antibacterial mechanisms of the flavonoids. For example, quercetin activity is partly responsible for inhibiting DNA gyrase. It has been observed that sophoraflavone $\mathrm{G}$ and epigallocatechin gallate hamper the energy metabolism of membrane cell function and licochalcones A and C (24). Flavonostilbenes have shown special antibacterial and antibiofilm activity against Staphylococcus epidermidis with minimum inhibitory concentration (MIC) values of 3.1 to $12.5 \mu \mathrm{g} /$ $\mathrm{mL}$ (25). Phenolic acids exist in our various diets such as foods made thanks to Fungi, which owing to their biological properties have been widely investigated so that there is evidence of their role in disease prevention. However, these compounds are metabolized in vivo, circulating as glucuronidated, sulfated and methylated metabolites and indicating higher or lower biological activity (26). The essential oils are complex compounds among the various types of volatile molecules such as terpenoids, aromatic compounds derived from phenols and aliphatic compounds, which have found many fans in pharmaceutical, health, cosmetic, agriculture and food industries (27). The essential oils have been used since the middle ages as bactericides, virucides, fungicides, disinfectants, insecticides and other purposes such as analgesics, sedatives, anti-inflammatory agents, spasmolytics and local anesthetics (28). Terpenoids and phenylpropanoids are the main components of essential oils that provide their biological properties (29). Sesquiterpenoids, and especially sesquiterpene lactones, 
from family Asteraceae play a pivotal role in human health as part of a balanced diet and pharmaceutical agents. Some sesquiterpene lactones have antimicrobial properties and can impair fungal and bacterial cell wall (30).

\section{The active ingredients of medicinal plants against $S$. aureus}

This article attempts to highlight the findings of previous studies regarding the antimicrobial effects of various herbal compounds on bacteria, including $S$. aureus and MRSA, in order to clarify the effects of medicinal plants on these bacteria. A comprehensive description of medicinal plants with antibacterial activities is presented bellow and a summary of them are listed in Table 1.

\section{Family Asteraceae}

The plants in family Asteraceae are of great interest owing to compounds such as flavonoids, saponins, steroids, alkaloids and glycosides. The active compounds in this family are sesquiterpene lactones, which are key secondary metabolites responsible for the antibacterial activity of this family (52,53). Xanthium strumarium extract showed significant effect on MSSA (25 mm) and MRSA (20 mm), which had more effect on MSSA. The results exhibited correlation of dose and sensitivity between the plant extract concentrations and bacterial growth inhibition. The antibacterial activity of this plant may be due to the presence of phenolic acids, flavonoids, tannins and terpenoids in the methanolic extracts (54). Hasson et al examined the antibacterial activity of ethanolic extract of Saussurea lappa root against multidrug resistant (MDR) bacteria, including MRSA. The results showed bacteriostatic effects at a concentration of $2000 \mu \mathrm{g} / \mathrm{mL}$ and a bactericidal effect at a concentration of $6000 \mu \mathrm{g} /$ $\mathrm{mL}$ on the MRSA. Therefore, this study investigated the herb as an antibiotic because one of the reasons may be attributed to the presence of a new source of antimicrobial agents with new potential mechanisms.

Systematic screening of molecules such as antibacterial agents may lead to the discovery of new active ingredients (55). Different extracts of Senecio tenuifolius Burm plant were evaluated on MRSA and MSSA. The results showed that the methanolic extract of this plant significantly reduced the growth of these bacteria. Then, the active ingredients of this plant were purified by column chromatography. Four fractions were obtained and the fraction 3 had an inhibitory effect on the strains studied, which showed the zone of inhibition (ZOI) diameter of $15.09,13.25,14.12 \mathrm{~mm}$, and the MIC values of 88.16 , 128.11 and $116.12 \mu \mathrm{g} / \mathrm{mL}$, respectively (56). These studies show the benefits of $S$. tenuifolius in treating skin infections. Talib et al investigated the antibacterial activity of 14 plants on various gram-positive and gramnegative bacteria. These plants displayed antibacterial effect on both bacterial groups, while their impacts were higher on gram-positive bacteria. One of the bacteria was MRSA. The results of the study showed that the MIC value was $500 \mu \mathrm{g} / \mathrm{mL}$ for butanol and aqueous extracts of Rosa damascene receptacles and $250 \mu \mathrm{g} / \mathrm{mL}$ for butanol extract of Inula viscosa flowers. The bacterium was sensitive to butanol extract of Rosa damascena receptacles (95\% inhibition), I. viscose flowers (92\% inhibition) and Verbascum sinaiticum flowers (70\% inhibition) (57). Investigating different fractions of methanolic extract of Atractylodes japonica root showed that the fraction of $\mathrm{CHCl} 3$ had a good antibacterial effect on $S$. aureus strains. The $\mathrm{MIC}$ value for the fraction of $\mathrm{CHCl} 3$ exhibited the antibacterial effect as equal as ampicillin $(32 \mu \mathrm{g} / \mathrm{mL})$ against MRSA ATCC33591. Purification of this fraction gave four compounds; the compound $4(6 \mathrm{E}$, 12E)-tetradecadiene-8, 10-diyne-1, 3-diol) possessed anti-MRSA activity at a MIC value of $4-32 \mu \mathrm{g} / \mathrm{mL}$. These results provide a promising basis for the potential use of this extract as well as the separation of its compounds for the treatment of bacterial infections (58).

During a research on Gynoxys verrucosa Wedd, which is one of the traditional southern Ecuadorian herbs, the results showed that the extract of this plant had a poor antibacterial activity. Purification and examination of the compounds of this plant extract showed that compound 1 (sesquiterpene lactones leucodine) had no antibacterial activity, but compound 2 (dehydroleucodine) had moderate antibacterial activity (MIC50 between 49 and $195 \mu \mathrm{g} / \mathrm{mL}$ ). This conclusion suggests that exocyclic conjugated methylene in the lactone ring is essential for the antibacterial activity of sesquiterpene lactones. In the compound 2 , in addition to the lactone ring carbonyl, there is a carbonyl in the opposite direction to the cycloheptane ring and perhaps the second hydrogen bonding site is required for this activity (59).

\section{Family Apocynaceae}

One of the folk Indian medicines used to treat skin infections is leaf and stem bark of Tabernaemontana alternifolia (Roxb). In studies, the MIC value was 600-800 $\mu \mathrm{g} / \mathrm{mL}$ for MRSA. The aqueous extract of this plant has shown antibacterial activity against MRSA and VRSA, and it has no cytotoxic effect that confirms the validity of this plant in traditional medicine and introduces it as a candidate for the treatment of MRSA infections (47). The methanolic extract of Tabernaemontana stapfiana Britten root and stem had good antibacterial activity. The zone of inhibition diameter of this extract was 9 to $19 \mathrm{~mm}$ higher than other bacteria, which showed the highest inhibitory effect on $S$. aureus $(\mathrm{ZOI}=19 \mathrm{~mm})$. The lowest MIC value was $15.6 \mathrm{mg} / \mathrm{ml}$, which was related to $S$. aureus. This potent antibacterial effect of methanolic extract can be attributed to the presence of alkaloids and saponins, which are antibacterial compounds. There are also other antibacterial compounds such as flavonoids 
Table 1. The list of medicinal plants and their antibacterial activities

\begin{tabular}{|c|c|c|c|c|c|c|}
\hline Source & Active compounds & Antibacterial assay method & Type extraction & Active against bacteria & $\operatorname{MIC}(\mu \mathrm{g} / \mathrm{mL})$ & Ref. \\
\hline $\begin{array}{l}\text { Laennecia confusa (Cronquist) G. } \\
\text { L. Nesom (Asteraceae). }\end{array}$ & $\begin{array}{l}\text { Triterpenes } \\
\text { Saponins } \\
\text { Flavonoids } \\
\text { Tannins }\end{array}$ & MIC & $\mathrm{N}$-hexane (hexane) & $\begin{array}{l}\text { E.coli } \\
\text { P. aeruginosa } \\
\text { K. pneumoniae } \\
\text { MRSA } \\
\text { Staphylococcus aureus }\end{array}$ & $\begin{array}{l}\text { NA } \\
\text { NA } \\
\text { NA } \\
1000 \\
1000\end{array}$ & (31) \\
\hline $\begin{array}{l}\text { Laennecia confusa (Cronquist) G. } \\
\text { L. Nesom (Asteraceae). }\end{array}$ & $\begin{array}{l}\text { Triterpenes } \\
\text { Saponins } \\
\text { Flavonoids } \\
\text { Tannins }\end{array}$ & MIC & Chloroform & $\begin{array}{l}\text { E.coli } \\
\text { P. aeruginosa } \\
\text { K. pneumoniae } \\
\text { MRSA } \\
\text { Staphylococcus aureus }\end{array}$ & $\begin{array}{l}\text { NA } \\
\text { NA } \\
\text { NA } \\
\text { NA } \\
1000\end{array}$ & (31) \\
\hline Psidium guineense Swartz & $\begin{array}{l}\text { Tannins, flavonoids, } \\
\text { condensed proanthocyanidins, } \\
\text { leucoanthocyanidins, and sugar }\end{array}$ & $\begin{array}{l}\text { MIC } \\
\text { MBC }\end{array}$ & Aqueous extract & MRSA & $\begin{array}{l}\text { Between } 250 \text { and } \\
500 \mu \mathrm{g} / \mathrm{mL}\end{array}$ & (32) \\
\hline $\begin{array}{l}\text { Goldenseal (Hydrastis } \\
\text { canadensis) }\end{array}$ & Alkaloid and flavonoid & $\begin{array}{l}\text { MIC, Quorum quenching assays } \\
\text { with fluorescent reporters, Quorum } \\
\text { quenching assay with lux reporter, } \\
\text { Human skin epithelia toxicity assay }\end{array}$ & Hydroethanolic extract & MRSA & 75 & (33) \\
\hline $\begin{array}{l}\text { C. circinalis and C. revoluta } \\
\text { leaflets }\end{array}$ & Biflavonoids & $\begin{array}{l}\text { MIC } \\
\text { MBC } \\
\text { IC50 }\end{array}$ & Methanolic extract & $\begin{array}{l}\text { Staphylococcus aureus } \\
\text { MRSA }\end{array}$ & $\begin{array}{l}17.5 / \\
35.9 / 37 \\
N A / 35.9 / 37\end{array}$ & (34) \\
\hline Abrus schimperi & Amorphaquinone and pendulone & $\begin{array}{l}\text { MIC } \\
\text { IC50 }\end{array}$ & Etoh extract & $\begin{array}{l}\text { Staphylococcus aureus } \\
\text { MRSA }\end{array}$ & $\begin{array}{l}10 / 2.5 \\
20 / 2.5\end{array}$ & (35) \\
\hline Bersama engleriana Gurke & $\begin{array}{l}\text { Flavonoids } \\
\text { Phenols } \\
\text { Triterpenes } \\
\text { Anthraquinones }\end{array}$ & $\begin{array}{l}\text { MIC } \\
\text { MBC } \\
\text { Peliminary phytochemical } \\
\text { investigations } \\
\text { Antitumor assays } \\
\text { Antioxidant assay } \\
\text { Acute oral toxicity study }\end{array}$ & Methanolic extracts & $\begin{array}{l}\text { Citrobacter freundii, Enterobacter cloacae, Escherichia } \\
\text { coli, Klebsiella pneumonia, Morganella morganii, } \\
\text { Proteus mirabilis, Pseudomonas aeruginosa, Shigella } \\
\text { dysenteriae, Salmonella typhi, Streptococcus faecalis, } \\
\text { Staphylococcus aureus, Bacillus cereus, Bacillus } \\
\text { stearothermophilus, Bacillus subtilis }\end{array}$ & 9.76 to 156.25 & (36) \\
\hline Xanthium strumarium & $\begin{array}{l}\text { Phenolic acids, flavonoids tannins, } \\
\text { triterpinoids }\end{array}$ & $\begin{array}{l}\text { Disc diffusion method } \\
\text { Paired diene method }\end{array}$ & Methanolic extract & MSSA, MRSA & - & (37) \\
\hline Holoptelea integrifolia & $\begin{array}{l}\text { Alkaloids, flavonoids tannins, } \\
\text { terpenoids, glycosides }\end{array}$ & $\begin{array}{l}\text { MIC } \\
\text { MMC } \\
\text { Agar well diffusion method } \\
\text { Folin-Ciocalteu } \\
\text { Colorimetric method }\end{array}$ & Methanolic extracts & $\begin{array}{l}\text { Bacillus cerculences, Pseudomonas aeruginosa, } \\
\text { Bacillus subtilis, Klebsiella aeruginosa, Staphylococcus } \\
\text { aureus, Escherichia coli }\end{array}$ & 62.5 to 1250 & (38) \\
\hline
\end{tabular}




\begin{tabular}{|c|c|c|c|c|c|c|}
\hline Piper umbellatum & $\begin{array}{l}\text { Flavonoid, alkaloid, terpene, } \\
\text { and sterolclasses }\end{array}$ & $\begin{array}{l}\text { MIC } \\
\text { Outer membrane permeability } \\
\text { IntracellularKp efflux } \\
\text { Nucleotide leakage }\end{array}$ & Hydroethanolic extract & $\begin{array}{l}\text { E.coli, K. pneumoniae, P. aeruginosa, S. typhimurium, } \\
\text { Shigella flexneri, E. faecalis, S. aureus, S.pyogenes, S. } \\
\text { epidermidis }\end{array}$ & $\begin{array}{l}12.5 \text { to } 25 \mathrm{mg} / \mathrm{mL} \\
>100 \mathrm{mg} / \mathrm{mL}\end{array}$ & (39) \\
\hline $\begin{array}{l}\text { Lemongrass, oregano, rosemary } \\
\text { thyme, neem, tulsi, aloe vera } \\
\text { bryophyllum }\end{array}$ & $\begin{array}{l}\text { Sugars, alkaloids, anthraquinones, } \\
\text { glycosides flavonoids tannins, steroids, } \\
\text { saponins, triterpenoids, phlobatanins }\end{array}$ & MIC agar well diffusion method & $\begin{array}{l}\text { Hexane, Chloroform, } \\
\text { Methanol, ethanol water } \\
\text { extract }\end{array}$ & $\begin{array}{l}\text { Multi-drug resistant Staphylococcus aureus } \\
\text { K. pneumoniae, E. coli. }\end{array}$ & $\begin{array}{l}1.56-6.25 \\
6.25-25\end{array}$ & (40) \\
\hline Helicanthus elastica & Phenolic composition & MIC agar well diffusion method & Ethanol extract & $\begin{array}{l}\text { A. hydrophila, K. pneumoniae, E.coli, V. fischeri, B. } \\
\text { subtilis, MRSA, P. aeruginosa, S. pyogenes, }\end{array}$ & 250 to 500 & (41) \\
\hline Blechnum orientale Linn & $\begin{array}{l}\text { Flavonoids, terpenoids, } \\
\text { Tannins }\end{array}$ & $\begin{array}{l}\text { Disc diffusion test } \\
\text { MIC } \\
\text { MBC }\end{array}$ & Methanol extract & $\begin{array}{l}\text { B. cereus, Micrococcus luteus, } \\
\text { MSSA, MRSA, S. epidermidis }\end{array}$ & $15.6-250$ & (43) \\
\hline Cocos nucifera & Procyanidins & $\begin{array}{l}\text { Agar diffusion method } \\
\text { MIC, MBC }\end{array}$ & Aqueous crude extract & $\begin{array}{l}\text { S. aureus } \\
\text { MRSA }\end{array}$ & $\begin{array}{l}1024 \\
1024\end{array}$ & (44) \\
\hline Clausena heptaphylla & $\begin{array}{l}\text { Flavonoids, alkaloids, saponins, } \\
\text { steroids, glycoside, carbohydrate }\end{array}$ & $\begin{array}{l}\text { Disc diffusion method } \\
\text { MIC }\end{array}$ & Ethanol extract & $\begin{array}{l}\text { B. subtilis, S. aureus, B. cereus, } \\
\text { B. polymyxa, B. megaterium, E. faecalis, } \\
\text { S. typhi, Klebsiella sp, S. flexneri, } \\
\text { S. sonnei, Proteus sp, E. coli }\end{array}$ & 2.000 to 3.500 & (45) \\
\hline Pupalia lappacea Juss & $\begin{array}{l}\text { Steroids, glycosides, saponins, } \\
\text { flavonoids, alkaloids, sugar and phenol }\end{array}$ & MIC, MBC & Methanolic extract & P. aeruginosa, S.aureus, B. subtilis & $9000,4000,3000$ & (46) \\
\hline Tabernaemontana alternifolia & $\begin{array}{l}\text { Alkaloids, flavonoids, coumarins, } \\
\text { saponins and steroids }\end{array}$ & $\begin{array}{l}\text { Disc diffusion method } \\
\text { MIC }\end{array}$ & Aqueous extracts & $\begin{array}{l}\text { B. subtilis, S. aureus (ATCC 6538P), S. epidermidis } \\
\text { (ATCC 12228), E. coli (ATCC 8739), MRSA (ATCC 43300), } \\
\text { VRSA }\end{array}$ & $600-800$ & (47) \\
\hline Chelidonium majus Linn & Alkaloids & $\begin{array}{l}\text { MICs } \\
\text { MBCs }\end{array}$ & $\begin{array}{l}\text { Methanolic extract (crude } \\
\text { extract and fractions) }\end{array}$ & MRSA & $0.49-15.63$ & (48) \\
\hline Premna resinosa & $\begin{array}{l}\text { Flavonoids, Anthraquinones, } \\
\text { Terpenoids, Phenols, Alkaloids }\end{array}$ & $\begin{array}{l}\text { Disc diffusion method } \\
\text { MIC } \\
\text { MBC }\end{array}$ & $\begin{array}{l}\text { Methanol crude extracts and } \\
\text { fractions) }\end{array}$ & $\begin{array}{l}\text { S. aureus, MRSA, E. coli, K. pneumoniae, P. aeruginosa, } \\
\text { S. typhi, S. sonnei, M. tuberculosis }\end{array}$ & $\begin{array}{l}31.25-125 \\
>6.25-50\end{array}$ & (49) \\
\hline $\begin{array}{l}\text { B. citriodora, T. ferdinandiana, } \\
\text { C. australasica, L. ponticum }\end{array}$ & Phenolic compounds & $\begin{array}{l}\text { Well diffusion assay } \\
\text { MIC } \\
\text { MBC }\end{array}$ & $\begin{array}{l}\text { Aqueous, ethanolic and } \\
\text { peptides extracts }\end{array}$ & $\begin{array}{l}\text { S. aureus, } \\
\text { E. coli, } \\
\text { B. cereus }\end{array}$ & $\begin{array}{l}>125-1.17 \\
125-1.17 \\
31.25-0.58\end{array}$ & (50) \\
\hline Terminalia fagifolia & $\begin{array}{l}\text { Terpenoidsglucocorticoids, flavonoids } \\
\text { polyphenols }\end{array}$ & $\begin{array}{l}\text { MIC } \\
\text { MBC }\end{array}$ & $\begin{array}{l}\text { Ethanol extract, } \\
\text { Hydroalcoholic fraction, } \\
\text { Aqueous fraction, } \\
\text { Water soluble fraction }\end{array}$ & $\begin{array}{l}\text { S. aureus (ATCC 29213), } \\
\text { S. aureus COL, S. aureus WB69, S.epidermidis (ATCC } \\
\text { 12228), S. epidermidis H111, S. epidermidis 7OD }\end{array}$ & $25-200$ & (51) \\
\hline
\end{tabular}


and coumarin that have synergistic effects (60). Wang et al examined the Alstonia scholaris plant and concluded that the plant had six pentacyclic terpenoids. Two compounds of oleanolic and ursolic acid have antibacterial activity limited to gram-positive bacteria. The ursolic acid had a synergistic effect along with ampicillin and tetracycline on two bacteria of $S$. aureus and Bacillus cereus. The ability of this compound to enhance the activity of antibiotics can be one of the most important therapeutic agents in the future (61).

\section{Family Labiatae (Lamiaceae)}

The ethanol extract of tulsi, thyme, oregano and rosemary plants belonging to Family Lamiaceae have promising broad spectrum antibacterial properties on MDR bacteria. The ZOI is between 6 to $20 \mathrm{~mm}$ in tulsi, 4 to $18 \mathrm{~mm}$ in oregano and rosemary, and 4 to $21 \mathrm{~mm}$ in thyme. The presence of tannins and saponins has been confirmed in all herbs. The MIC value in the Ocimum tenuiflorum plant was $\leq 3.12 \mathrm{mg} / \mathrm{ml}$ for $S$. aureus and MRSA, which could be due to the fact that flavonoids and tannins are the main components of this plant against MRSA (40).

The two compounds of oleanolic acid and ursolic acid from Salvia officinalis (Sage) leaves showed antibacterial activity on vancomycin-resistant enterococci, Streptococcus pneumoniae and MRSA. The antimicrobial activity of ursolic acid on vancomycin-resistant enterococci suspension and S. pneumoniae and MRSA were twice as strong as oleanolic acid, which was calculated from the values obtained from MIC (62). Although the antibacterial activity of oleanolic acid and ursolic acid is not as strong as the antimicrobial drugs used in the clinic, its antibacterial activity is relatively acceptable as a plant-derived compound. Premna resinosa is one of the traditional herbs used for respiratory diseases. The findings highlighted the anti-Mycobacterium tuberculosis, anti-bacterial and antifungal activity of this plant. The fraction of dichloromethane had the highest MIC on MRSA $(31.25 \mu \mathrm{g} / \mathrm{mL})$ and the fraction of ethyl acetate had the highest ZOI diameter $(22.3 \pm 0.3 \mathrm{~mm})$ on S. aureus. The effects of this plant can be related to its alkaloids, flavonoids, terpenoids, anthraquinones and phenols (49). Reports suggest an inhibitory effect of the 5-hydroxy-1,4naphthalenedione composition of the Teak leaf on Listeria monocytogenes and MRSA (63). The leaves of Rosmarinus officinalis and Tecoma capensis have a moderate antiquorum sensing activity (64). Family Labiatae can be widely used as a natural source derived from plants against MRSA (65).

\section{Family Ranunculaceae}

The goldenseal (Hydrastis canadensis L.) plant is traditionally used for skin diseases (66). LC-MS method was used to detect alkaloids and flavonoids in this extract as inhibitors of efflux pump. The extract of this plant has anti-quorum sensing activity on MRSA, which can be due to the reduction of cell signaling through the twocomponent regulatory system (TCS) of AgrCA. This extract also inhibits the production of MRSA toxin and damage to keratinocytes, in vitro (33-67).

\section{Family Polygonaceae}

Polygonum aviculare and Polygonum cuspidatum are the plants from family Polygonaceae with antibacterial activity on S. aureus (68). The ethanolic extract of Rumex nervosus has an inhibitory effect on gram-positive and gramnegative bacteria, while the hexane extract of this plant has a relatively mild antibacterial activity on gram-negative bacteria such as E. coli and Pseudomonas aeruginosa, but both extracts inhibit Candida albicans. The aqueous extract of this plant has a dose-dependent inhibitory effect on S. aureus and MRSA (69). In the essential oils extracted from Polygonum minus, GCMS showed different compounds, including aliphatic compounds such as decanal and dodecanal. The antibacterial activity of nonpolar extracts (n-hexane) showed higher antimicrobial activity on MRSA compared to polar extracts (70).

\section{Family Solanaceae}

Methanolic extract of Withania somnifera leaves from family Solanaceae on gram-positive bacteria including S. aureus and Enterococcus showed the ZOI diameters of 20.6 and $19.4 \mathrm{~mm}$, respectively, at a concentration of $2 \mathrm{mg} / \mathrm{mL}$ (71). The antimicrobial activity of methanolic extracts of various organs of Bersama engleriana (family Melianthaceae) on different microorganisms including gram-positive bacteria, gram-negative bacteria, Candida and mycobacterium showed that the MICs were between 9.76 to $156.25 \mu \mathrm{g} / \mathrm{mL}$. These activities were attributed to the presence of flavonoids, terpenoids, anthraquinones and phenols (36).

\section{Family Urticaceae}

The methanolic extract of Urtica dioica (family Urticaceae) has antibacterial properties, which can be due to the presence of antibacterial compounds (208.37 \pm 4.39 $=$ phenols, $20.29 \pm 0.48=$ flavonoids, and $22.83 \pm 0.30=$ flavonols). The reported MICs for this extract were 9.59 to $149.93 \mathrm{mg} / \mathrm{ml}(72,73)$.

\section{Family Piperaceae}

The hydroalcoholic extract of Piper umbellatum (family Piperaceae) leaves has antibacterial activity and low toxicity in vitro and in vivo. Its mechanism of action is related to the change in the cell membrane and wall permeability that can be linked at least to the presence of flavonoid spresentin (39).

\section{Family Poaceae}

Dahiya showed that hexane and chloroform extracts of lemongrass were not effective on the tested bacteria ( $S$. aureus, MRSA, E. coli, Klebsiella pneumoniae and Proteus 
mirabilis). S. aureus ATCC 25923 had the most sensitivity to the tested extracts (neem, tulsi, oregano, rosemary, aloevera, thyme) except for hexane and chloroform extracts of lemongrass. The highest MIC of Lemongrass extract against $S$. aureus was $12.5 \mathrm{mg} / \mathrm{mL}$ (42). Eleucine indica (Poaceae) is a tropical plant. It is resistant to environmental conditions and is used for many diseases, including influenza, increased blood pressure and so on. In addition to antioxidant, it showed to have anti-bacterial properties and its hexane extract exhibited significant activities against MRSA and $P$. aeruginosa (74). Another species of this family is Bromus inermis Leyss, which contains flavonoids. The hexane extract of this plant (MIC $=8 \mu \mathrm{g} / \mathrm{mL}$ ) had significant effects on MRSA (75).

\section{Family Rosaceae}

The Rosa canina L. (red rose) plant contains compounds such as tellimagrandin I and rugosin B that decrease MIC values of L-lactam antibiotics against MRSA (76). The Fructus crataegi (hawthorn) also contains catechin, epicatechin gallate and epigallocatechin, which increase the effect of $\beta$-lactam antibiotics whose mechanism of action is through the suppression of genes (nor A, nor $\mathrm{C}$ and abc A) involved in the efflux pump (77). Rosa damascena Mill is another plant in this family, whose antiMRSA effect has been confirmed in previous researches (36).

\section{Family Myrtaceae}

The essential oils obtained from various species of Melaleuca plant have been effective against $S$. aureus isolated from the ulcer of patients (78). In a study by Razmavar et al on Baeckea frutescens L. plant from this family, the findings revealed that the leaf extract of this plant has active ingredients, including flavonoids, alkaloids, steroids, terpenoids, phenols and carbohydrates. The antibacterial activity of this extract is related to these compounds (79). The ethanol extract of Rhodomyrtus tomentosa showed good antibacterial activity. Proteome analyzes revealed the effects of this plant on the expression of several major functional classes of MRSA cell proteins, including proteins responsible for biosynthesis of cell wall and cell division, surface antigens, and virulence factors. The effects of this plant on morphology and superstructure changes in treated bacteria were confirmed using transmission electron micrographs. Significant changes were observed, including changes in the cell wall, abnormal septum, cellular collapse and lysis (80). The combination of aqueous extract of Psidium guineense Swartz with $\beta$-lactam antibiotics, fluoroquinolones and carbapenems showed synergistic effects against the MRSA strains (32).

\section{Family Rutaceae}

The ethanolic extract of Clausena heptaphylla (from family Rutaceae) stem bark has alkaloids, flavonoids, saponins and steroids, but lacks tannins, anthraquinones and resins. This extract was effective on a large number of bacteria, including $S$. aureus. In addition to strong antioxidant properties, this plant showed better effects on gram-positive $(\mathrm{ZOI}=6.5-9.0 \mathrm{~mm})$ than gram-negative $(\mathrm{ZOI}=3.0-4.5 \mathrm{~mm})$ bacteria $(45)$.

\section{Family Lauraceae}

Falodun et al suggested that the Persea americana plant is effective on both fungi and bacteria (81). The petroleum ether extract of the plant has an excellent antibacterial activity against MRSA with an IC50 value of $7.8 \mu \mathrm{g} / \mathrm{mL}$ (82). The extract of Laurus nobilis leaves has also shown a potent anti-MRSA activity $(\mathrm{ZOI}=25 \mathrm{~mm})$ and an antiquorum sensing activity ( $>17 \mathrm{~mm}$ ) (46). Ethyl acetate fraction from Cinnamomum iners standardized leave has a strong antibacterial activity, especially against MRSA and E. coli with the MIC values of 100 and $200 \mu \mathrm{g} / \mathrm{mL}$, respectively. Xanthorrhizol (5- (1,5-dimethyl-4-hexenyl) -2-methylphenol) was identified by different spectroscopic techniques in this plant, as the mentioned properties can be due to the presence of this compound (83).

\section{Family Combretaceae}

Ethanol extract and stem bark fractions of Terminalia fagifolia exposed good anti-MRSA activity (MIC=25$200 \mu \mathrm{g} / \mathrm{mL}$ and minimum bactericidal concentration $(\mathrm{MBC})=200-400 \mu \mathrm{g} / \mathrm{mL})$. They also inhibited more than $80 \%$ biofilm formation. The images of Atomic Force Microscopy (AFM) also showed the morphological changes of the aqueous fraction of this plant on the surface of the S. aureus ATCC29213 (51). Terminalia ivorensis has traditionally been used to treat dermatological disorders, which can be due to the presence of tannins, saponins, flavonoids, coumarins and polyphenols (84).

\section{Family Theaceae}

Camellia sinensis plant from family Theaceae has antibacterial activity against MDR bacteria such as MRSA and MDR P. aeruginosa (85-86).

\section{Family Fagaceae}

One of the members of family Fagaceae is Quercus infectoria, which is traditionally used for skin and wound infections, probably due to the presence of more than $70 \%$ tannin. It contains ellagic acid, gallic acid, syringic acid and tannic acid. This plant has shown good antibacterial activity, which leads to an increased sensitivity of MRSA to high and low osmotic pressure (87). The synergistic effect of this plant with $\beta$-lactam antibiotics has been shown to interfere with staphylococcal enzymes such as autolysins and $\beta$-lactamase (88). This plant also had antibiofilm effects through its effect on the bacterial cell wall (89).

\section{Family Fabaceae}

The antibacterial compounds were obtained from the 
polar fractions of Ononis hirta (a.p) and Ononis sicula (a.p). The antibacterial activity was well observed on many bacteria, including $S$. aureus and Bacillus cereus, which are causes of food poisoning. These plants contain flavonoids and terpenoids (36). Two new flavonoids, called bakuisoflavone and bakuflavanone, were identified in the Psoralea corylifolia fruit; these compounds exhibited significant anti-MRSA effects (90). In the genus Abrus from this family, amorphaquinone and pendulone compounds have been shown to be effective not only against Leishmania donovani and Plasmodium falciparum, but also on S. aureus and MRSA (35).

\section{Family Loranthaceae}

Helicanthus elastica (Desr.) Danser plant belonging to family Loranthaceae did not affect MRSA bacteria, but was more effective on gram-negative bacteria, especially Klebsiella pneumoniae (41). The plants of Ephedra procera (Ephedraceae) (42), Eleutherine americana Merr (Iridaceae) (91), Blechnum orientale Linn. (Blechnaceae) (43), Cocos nucifera (Arecaceae) (44), Chelidonium majus Linn (Papaveraceae) (48), Labisia pumila Benth (Myrsinaceae) (92), Cytinus hypocistis (Cistaceae) (93), Sonneratia caseolaris Linn (Sonneratiaceae) (94), Turnera ulmifolia (Turneraceae) (95), Plectranthus amboinicus (Lour.) Spreng (96), have been effective on different bacteria, including MRSA, which can be investigated as anti-MRSA candidates.

A large number of studies have been carried out on the identification of the antimicrobial effects of plant compounds on different microbial agents (97), which have also yielded favorable results. Wild plants have bioactive ingredients with potential activity against diseases associated with microorganisms (98). Zhang et al examined 58 traditional herbs and argued that their findings were consistent with the traditional use of these herbs. By detecting and isolating the potential substances of these plants, they can be used to discover a new antimicrobial agent for treatments (50).

\section{Clinical trials}

In addition to in vitro use of plants, researchers have investigated the in vivo effects of these plants on different bacteria, including MRSA; remarkable effects of these plants have been reported on inhibiting this bacterium $(91,98)$. Yamada et al examined the inhaled effect of catechin tea on aged patients with cerebrovascular ailments whose sputum contained MRSA. These patients were exposed to the herb inhaled three times a day for three weeks. The results showed that the reduction in MRSA count in the sputum was $47 \%$ in the treatment group and $15 \%$ in the control group and this difference was significant. Although the inhalation of this plant has reduced the count of this bacterium, its use to control the MRSA-associated infections is controversial (99). Buenz et al stated that the Atun tree (Atuna racemosa) is one of the plants identified in the 400-year book of plant history to heal the MRSA-related infections. They showed that the Atun tree extract at the doses of 10 times greater than MIC value are effective against MRSA for topical use in humans (100). Tea tree oil is one of the ingredients traditionally used to treat skin diseases, as researchers have confirmed the effects of these compounds. The body washing with these compounds can prevent colonization of microorganisms on the body (101-103).

\section{Conclusion}

The emergence of expanding antibiotic-resistance genes in the bacterial population has led to the identification of new antimicrobial drugs. The most promising of these compounds are drugs affecting microorganisms through various mechanisms to eliminate microorganisms with subsequent drug actions in case of resistance to a mechanism, hereby contributing to treat MDR bacterial infections. Consequently, there is a need for concentration to detect the active components of these compounds, as well as to pursue simultaneously the development of this product as a natural product. The results of this study showed that different plants belonging to various families have the ability to inhibit S. aureus and MRSA and can be used to achieve effective drugs against these bacteria. Considering the synergistic effects of some of these plants with antibiotics used in the clinic, it is suggested to be evaluated the combined effects of different parts of the plants in combination with antibiotics in future studies.

\section{Authors' contributions}

MA, HM GGH and AG contributed to the idea of the study, its design and interpretation. The manuscript was prepared by HM, FJN, FGH, SH and BM and the final version was approved by all authors.

\section{Conflict of interest}

None to declare.

\section{Ethical considerations}

Ethical issues have been observed by the authors.

\section{Funding/Support}

None.

\section{References}

1. Grundmann H, Aires-de-Sousa M, Boyce J, Tiemersma E. Emergence and resurgence of meticillin-resistant Staphylococcus aureus as a public-health threat. Lancet. 2006;368(9538):874-85. doi: 10.1016/s01406736(06)68853-3.

2. Safdar N, Bradley EA. The risk of infection after nasal colonization with Staphylococcus aureus. Am J Med. 2008;121(4):310-5. doi: 10.1016/j.amjmed.2007.07.034.

3. Deurenberg RH, Stobberingh EE. The evolution of 
Staphylococcus aureus. Infect Genet Evol. 2008;8(6):747-63. doi: $\quad$ 10.1016/j.meegid.2008.07.007.

4. Khosravi AD, Hoveizavi H, Farshadzadeh Z. The prevalence of genes encoding leukocidins in Staphylococcus aureus strains resistant and sensitive to methicillin isolated from burn patients in Taleghani Hospital, Ahvaz, Iran. Burns. 2012;38(2):247-51. doi: 10.1016/j.burns.2011.08.002.

5. Cheung GY, Otto M. The potential use of toxin antibodies as a strategy for controlling acute Staphylococcus aureus infections. Expert Opin Ther Targets. 2012;16(6):601-12. doi: $10.1517 / 14728222.2012 .682573$.

6. Klein E, Smith DL, Laxminarayan R. Hospitalizations and deaths caused by methicillin-resistant Staphylococcus aureus, United States, 1999-2005. Emerg Infect Dis. 2007;13(12):1840-6. doi: 10.3201/eid1312.070629.

7. Hoseini Alfatemi SM, Motamedifar M, Hadi N, Sedigh Ebrahim Saraie H. Analysis of Virulence Genes Among Methicillin Resistant Staphylococcus aureus (MRSA) Strains. Jundishapur J Microbiol. 2014;7(6):e10741. doi: 10.5812/jjm.10741.

8. Moellering RC, Jr. MRSA: the first half century. J Antimicrob Chemother.2012;67(1):4-11.doi:10.1093/jac/dkr437.

9. Ayliffe GA. The progressive intercontinental spread of methicillin-resistant Staphylococcus aureus. Clin Infect Dis. 1997;24 Suppl 1:S74-9.

10. Zapun A, Contreras-Martel C, Vernet T. Penicillin-binding proteins and beta-lactam resistance. FEMS Microbiol Rev. 2008;32(2):361-85. doi: 10.1111/j.1574-6976.2007.00095.x.

11. Fritz SA, Garbutt J, Elward A, Shannon W, Storch GA. Prevalence of and risk factors for communityacquired methicillin-resistant and methicillin-sensitive Staphylococcus aureus colonization in children seen in a practice-based research network. Pediatrics. 2008;121(6):1090-8. doi: 10.1542/peds.2007-2104.

12. Hanssen AM, Ericson Sollid JU. SCCmec in staphylococci: genes on the move. FEMS Immunol Med Microbiol. 2006;46(1):8-20. doi: 10.1111/j.1574-695X.2005.00009.x.

13. Elston JW, Barlow GD. Community-associated MRSA in the United Kingdom. J Infect. 2009;59(3):149-55. doi: 10.1016/j.jinf.2009.07.001.

14. Stefani S, Chung DR, Lindsay JA, Friedrich AW, Kearns $\mathrm{AM}$, Westh $\mathrm{H}$, et al. Meticillin-resistant Staphylococcus aureus (MRSA): global epidemiology and harmonisation of typing methods. Int J Antimicrob Agents. 2012;39(4):27382. doi: 10.1016/j.ijantimicag.2011.09.030.

15. Momtaz H, Hafezi L. Meticillin-resistant Staphylococcus aureus isolated from Iranian hospitals: virulence factors and antibiotic resistance properties. Bosn J Basic Med Sci. 2014;14(4):219-26. doi: 10.17305/bjbms.2014.4.34.

16. Jayaraman R. Antibiotic resistance: an overview of mechanisms and a paradigm shift. Curr Sci. 2009;96(11):1475-84.

17. Ke F, Yadav PK, Ju LZ. Herbal medicine in the treatment of ulcerative colitis. Saudi J Gastroenterol. 2012;18(1):3-10. doi: 10.4103/1319-3767.91726.

18. Jeong TY, Park BK, Cho JH, Kim YI, Ahn YC, Son CG. A prospective study on the safety of herbal medicines, used alone or with conventional medicines. J Ethnopharmacol. 2012;143(3):884-8. doi: 10.1016/j.jep.2012.08.016.

19. Calo JR, Crandall PG, O'Bryan CA, Ricke SC. Essential oils as antimicrobials in food systems-A review. Food Control. 2015;54:111-9. doi: 10.1016/j.foodcont.2014.12.040.

20. Niggemann B, Gruber C. Side-effects of complementary and alternative medicine. Allergy. 2003;58(8):707-16.

21. Prakash S, Shelke AU. Role of Triphala in dentistry. J Indian Soc Periodontol. 2014;18(2):132-5. doi: 10.4103/0972124x.131299.

22. Golestani MR, Rad M, Bassami M, Afkhami-Goli A. Analysis and evaluation of antibacterial effects of new herbal formulas, AP-001 and AP-002, against Escherichia coli O157:H7. Life Sci. 2015;135:22-6. doi: 10.1016/j. lfs.2015.05.007.

23. Rios JL, Recio MC. Medicinal plants and antimicrobial activity. J Ethnopharmacol. 2005;100(1-2):80-4. doi: 10.1016/j.jep.2005.04.025.

24. Cushnie TP, Lamb AJ. Antimicrobial activity of flavonoids. Int J Antimicrob Agents. 2005;26(5):343-56.

25. Wan CX, Luo JG, Ren XP, Kong LY. Interconverting flavonostilbenes with antibacterial activity from Sophora alopecuroides. Phytochemistry. 2015;116:290-7. doi: 10.1016/j.phytochem.2015.02.022.

26. Heleno SA, Martins A, Queiroz MJ, Ferreira IC. Bioactivity of phenolic acids: metabolites versus parent compounds: a review. Food Chem. 2015;173:501-13. doi: 10.1016/j. foodchem.2014.10.057.

27. Raut JS, Karuppayil SM. A status review on the medicinal properties of essential oils. Ind Crops Prod. 2014;62:250-64. doi: 10.1016/j.indcrop.2014.05.055.

28. Bilia AR, Guccione C, Isacchi B, Righeschi C, Firenzuoli F, Bergonzi MC. Essential oils loaded in nanosystems: a developing strategy for a successful therapeutic approach. Evid Based Complement Alternat Med. 2014;2014:651593. doi: 10.1155/2014/651593.

29. Prakash B, Kedia A, Mishra PK, Dubey NK. Plant essential oils as food preservatives to control moulds, mycotoxin contamination and oxidative deterioration of agri-food commodities-potentials and challenges. Food Control. 2015;47:381-91. doi: 10.1016/j.foodcont.2014.07.023.

30. Mahmoudi H, Arabestani MR, Molavi M, Shirzadi Karamolah K, Zare Fahim N. The study effects antimicrobial of Foeniculum vulgare mill and Achilles mille folium plant on bacterial pathogens causing urinary tract infections and nosocomial infection. Int J Pharmacogn Phytochem Res. 2016;8(9):1549-54.

31. Martinez Ruiz MG, Richard-Greenblatt M, Juarez ZN, Av-Gay Y, Bach H, Hernandez LR. Antimicrobial, anti-inflammatory, antiparasitic, and cytotoxic activities of Laennecia confusa. ScientificWorldJournal. 2012;2012:263572. doi: 10.1100/2012/263572.

32. Fernandes TG, de Mesquita AR, Randau KP, Franchitti AA, Ximenes EA. In vitro synergistic effect of Psidium guineense (Swartz) in combination with antimicrobial agents against methicillin-resistant Staphylococcus aureus strains. ScientificWorldJournal. 2012;2012:158237. doi: 10.1100/2012/158237.

33. Cech NB, Junio HA, Ackermann LW, Kavanaugh JS, Horswill AR. Quorum quenching and antimicrobial activity of goldenseal (Hydrastis canadensis) against methicillin-resistant Staphylococcus aureus (MRSA). Planta Med. 2012;78(14):1556-61. doi: 10.1055/s-0032-1315042. 
34. Moawad A, Hetta M, Zjawiony JK, Jacob MR, Hifnawy M, Marais JP, et al. Phytochemical investigation of Cycas circinalis and Cycas revoluta leaflets: moderately active antibacterial biflavonoids. Planta Med. 2010;76(8):796-802. doi: $10.1055 / \mathrm{s}-0029-1240743$.

35. Rahman AA, Samoylenko V, Jain SK, Tekwani BL, Khan SI, Jacob MR, et al. Antiparasitic and antimicrobial isoflavanquinones from Abrus schimperi. Nat Prod Commun. 2011;6(11):1645-50.

36. Kuete V, Mbaveng AT, Tsaffack M, Beng VP, Etoa FX, Nkengfack AE, et al. Antitumor, antioxidant and antimicrobial activities of Bersama engleriana (Melianthaceae). J Ethnopharmacol. 2008;115(3):494-501. doi: $\quad 10.1016 /$ j.jep.2007.10.027.

37. Rad JS, Alfatemi SM, Rad MS, Iriti M. In-vitro antioxidant and antibacterial activities of Xanthium strumarium L. extracts on methicillin-susceptible and methicillin-resistant Staphylococcus aureus. Anc Sci Life. 2013;33(2):109-13. doi: 10.4103/0257-7941.139050.

38. Srinivas Reddy B, Kiran Kumar Reddy R, Naidu VG, Madhusudhana K, Agwane SB, Ramakrishna S, et al. Evaluation of antimicrobial, antioxidant and wound-healing potentials of Holoptelea integrifolia. J Ethnopharmacol. 2008;115(2):249-56. doi: 10.1016/j.jep.2007.09.031.

39. da Silva IF Jr, de Oliveira RG, Mendes Soares I, da Costa Alvim T, Donizeti Ascencio S, de Oliveira Martins DT. Evaluation of acute toxicity, antibacterial activity, and mode of action of the hydroethanolic extract of Piper umbellatum L. J Ethnopharmacol. 2014;151(1):137-43. doi: 10.1016/j. jep.2013.10.011.

40. Dahiya P, Purkayastha S. Phytochemical screening and antimicrobial activity of some medicinal plants against multi-drug resistant bacteria from clinical isolates. Indian J Pharm Sci. 2012;74(5):443-50. doi: 10.4103/0250474x. 108420.

41. Sunil Kumar KN, Saraswathy A, Amerjothy S, Ravishankar B. Antimicrobial Potential of Helicanthus elastica (Desr.) Danser - A less explored Indian mistletoe growing on Mango trees. Journal of Traditional and Complementary Medicine. 2014;4(4):258-62.

42. Dehkordi NV, Kachouie MA, Pirbalouti AG, Malekpoor F, Rabei M. Total phenolic content, antioxidant and antibacterial activities of the extract of Ephedra procera Fisch. et Mey. Acta Pol Pharm. 2015;72(2):341-5.

43. Lai HY, Lim YY, Kim KH. Blechnum orientale Linn - a fern with potential as antioxidant, anticancer and antibacterial agent. BMC Complement Altern Med. 2010;10:15. doi: 10.1186/1472-6882-10-15.

44. Silva RR, Oliveira e Silva D, Fontes HR, Alviano CS, Fernandes PD, Alviano DS. Anti-inflammatory, antioxidant, and antimicrobial activities of Cocos nucifera var. typica. BMC Complement Altern Med. 2013;13:107. doi: $\quad 10.1186 / 1472-6882-13-107$.

45. Fakruddin M, Mannan KS, Mazumdar RM, Afroz H. Antibacterial, antifungal and antioxidant activities of the ethanol extract of the stem bark of Clausena heptaphylla. BMC Complement Altern Med. 2012;12:232. doi: 10.1186/1472-6882-12-232.

46. Udegbunam SO, Udegbunam RI, Muogbo CC, Anyanwu MU, Nwaehujor CO. Wound healing and antibacterial properties of methanolic extract of Pupalia lappacea Juss in rats. BMC Complement Altern Med. 2014;14:157. doi: 10.1186/1472-6882-14-157.

47. Marathe NP, Rasane MH, Kumar H, Patwardhan AA, Shouche YS, Diwanay SS. In vitro antibacterial activity of Tabernaemontana alternifolia (Roxb) stem bark aqueous extracts against clinical isolates of methicillin resistant Staphylococcus aureus. Ann Clin Microbiol Antimicrob. 2013;12:26. doi: 10.1186/1476-0711-12-26.

48. Zuo GY, Meng FY, Hao XY, Zhang YL, Wang GC, Xu GL. Antibacterial alkaloids from Chelidonium majus Linn (Papaveraceae) against clinical isolates of methicillinresistant Staphylococcus aureus. J Pharm Pharm Sci. 2008;11(4):90-4.

49. Njeru SN, Obonyo MA, Nyambati SO, Ngari SM. Antimicrobial and cytotoxicity properties of the crude extracts and fractions of Premna resinosa (Hochst.) Schauer (Compositae): Kenyan traditional medicinal plant. BMC Complement Altern Med. 2015;15:295. doi: 10.1186/ s12906-015-0811-4.

50. Shami AM, Philip K, Muniandy S. Synergy of antibacterial and antioxidant activities from crude extracts and peptides of selected plant mixture. BMC Complement Altern Med. 2013;13:360. doi: 10.1186/1472-6882-13-360.

51. de Araujo AR, Quelemes PV, Perfeito ML, de Lima LI, Sa MC, Nunes PH, et al. Antibacterial, antibiofilm and cytotoxic activities of Terminalia fagifolia Mart. extract and fractions. Ann Clin Microbiol Antimicrob. 2015;14:25. doi: 10.1186/s12941-015-0084-2.

52. Da Costa FB, Terfloth L, Gasteiger J. Sesquiterpene lactone-based classification of three Asteraceae tribes: a study based on self-organizing neural networks applied to chemosystematics. Phytochemistry. 2005;66(3):345-53. doi: 10.1016/j.phytochem.2004.12.006.

53. Constabel CP, Balza F, Towers GHN. Dithiacyclohexadienes and thiophenes of Rudbeckia hirta. Phytochemistry. 1988;27(11):3533-5. doi: 10.1016/0031-9422(88)80762-3.

54. Hasson SS, Al-Balushi MS, Alharthy K, Al-Busaidi JZ, Aldaihani MS, Othman MS, et al. Evaluation of antiresistant activity of Auklandia (Saussurea lappa) root against some human pathogens. Asian Pac J Trop Biomed. 2013;3(7):557-62. doi: 10.1016/s2221-1691(13)60113-6.

55. Manubolu M, Goodla L, Ravilla S, Obulum VR. Activityguided isolation and identification of anti-staphylococcal components from Senecio tenuifolius Burm. F. leaf extracts. Asian Pac J Trop Biomed. 2013;3(3):191-5. doi: 10.1016/ s2221-1691(13)60048-9.

56. Talib WH, Mahasneh AM. Antimicrobial, cytotoxicity and phytochemical screening of Jordanian plants used in traditional medicine. Molecules. 2010;15(3):1811-24. doi: 10.3390/molecules 15031811.

57. Jeong SI, Kim SY, Kim SJ, Hwang BS, Kwon TH, Yu KY, et al. Antibacterial activity of phytochemicals isolated from Atractylodes japonica against methicillin-resistant Staphylococcus aureus. Molecules. 2010;15(10):7395-402. doi: 10.3390/molecules15107395.

58. Ordonez PE, Quave CL, Reynolds WF, Varughese KI, Berry B, Breen PJ, et al. Sesquiterpene lactones from Gynoxys verrucosa and their anti-MRSA activity. J Ethnopharmacol. 2011;137(2):1055-9. doi: 10.1016/j.jep.2011.07.012.

59. Ruttoh EK, Tarus PK, Bii CC, Machocho AK, Karimie LK, Okemo PO. Antibacterial activity of Tabernaemontana 
stapfiana Britten (Apocynaceae) extracts. Afr J Tradit Complement Altern Med. 2009;6(2):186-94.

60. Wang CM, Chen HT, Wu ZY, Jhan YL, Shyu CL, Chou $\mathrm{CH}$. Antibacterial and Synergistic Activity of Pentacyclic Triterpenoids Isolated from Alstonia scholaris. Molecules. 2016;21(2):139. doi: 10.3390/molecules21020139.

61. Horiuchi K, Shiota S, Hatano T, Yoshida T, Kuroda T, Tsuchiya T. Antimicrobial activity of oleanolic acid from Salvia officinalis and related compounds on vancomycin-resistant enterococci (VRE). Biol Pharm Bull. 2007;30(6):1147-9.

62. Neamatallah A, Yan L, Dewar SJ, Austin B. An extract from teak (Tectona grandis) bark inhibited Listeria monocytogenes and methicillin resistant Staphylococcus aureus. Lett Appl Microbiol. 2005;41(1):94-6. doi: 10.1111/j.1472765X.2005.01680.x.

63. Al-Hussaini R, Mahasneh AM. Microbial growth and quorum sensing antagonist activities of herbal plants extracts. Molecules. 2009;14(9):3425-35. doi: 10.3390/ molecules 14093425 .

64. Coutinho HD, Costa JG, Lima EO, Falcao-Silva VS, Siqueira-Junior JP. Potentiating effect of Mentha arvensis and chlorpromazine in the resistance to aminoglycosides of methicillin-resistant Staphylococcus aureus. In Vivo. 2009;23(2):287-9.

65. Brown AR, Ettefagh KA, Todd D, Cole PS, Egan JM, Foil $\mathrm{DH}$, et al. A mass spectrometry-based assay for improved quantitative measurements of efflux pump inhibition. PLoS One. 2015;10(5):e0124814. doi: 10.1371/journal. pone.0124814.

66. Zhang L, Ravipati AS, Koyyalamudi SR, Jeong SC, Reddy N, Bartlett J, et al. Anti-fungal and anti-bacterial activities of ethanol extracts of selected traditional Chinese medicinal herbs. Asian Pac J Trop Med. 2013;6(9):673-81. doi: 10.1016/s1995-7645(13)60117-0.

67. Al-Asmari AR, Siddiqui YM, Athar MT, Al-Buraidi A, AlEid AS, Horaib GB. Antimicrobial activity of aqueous and organic extracts of a Saudi medicinal plant: Rumex nervosus. J Pharm Bioallied Sci. 2015;7(4):300-3. doi: 10.4103/09757406.168031.

68. Ahmad R, Baharum SN, Bunawan H, Lee M, Mohd Noor $\mathrm{N}$, Rohani ER, et al. Volatile profiling of aromatic traditional medicinal plant, Polygonum minus in different tissues and its biological activities. Molecules. 2014;19(11):19220-42. doi: $10.3390 /$ molecules 191119220 .

69. Bisht P, Rawat V. Antibacterial activity of Withania somnifera against Gram-positive isolates from pus samples. Ayu. 2014;35(3):330-2. doi: 10.4103/0974-8520.153757.

70. Salehzadeh A, Asadpour L, Naeemi AS, Houshmand E. Antimicrobial activity of methanolic extracts of Sambucus ebulus and Urtica dioica against clinical isolates of methicillin resistant Staphylococcus aureus. Afr J Tradit Complement Altern Med. 2014;11(5):38-40.

71. Kukric ZZ, Topalic-Trivunovic LN, Kukavica BM, Matos SB, Pavicic SS, Boroja MM, et al. Characterization of antioxidant and antimicrobial activities of nettle leaves (Urtica dioica L.). Acta Period Technol. 2012;43:257-72.

72. Al-Zubairi AS, Abdul AB, Abdelwahab SI, Peng CY, Mohan S, Elhassan MM. Eleucine indica possesses antioxidant, antibacterial and cytotoxic properties. Evid Based Complement Alternat Med. 2011;2011:965370. doi: 10.1093/ecam/nep091.

73. Aliahmadi A, Mirzajani F, Ghassempour A, Sonboli A. Bioassay guided fractionation of an anti-methicillinresistant Staphylococcus aureus flavonoid from Bromus inermis Leyss Inflorescences. Jundishapur J Microbiol. 2014;7(12):e12739. doi: 10.5812/jjm.12739.

74. Shiota S, Shimizu M, Mizusima T, Ito H, Hatano T, Yoshida $\mathrm{T}$, et al. Restoration of effectiveness of betalactams on methicillin-resistant Staphylococcus aureus by tellimagrandin I from rose red. FEMS Microbiol Lett. 2000;185(2):135-8. doi: 10.1111/j.1574-6968.2000. tb09051.x.

75. Qin R, Xiao K, Li B, Jiang W, Peng W, Zheng J, et al. The combination of catechin and epicatechin callate from Fructus Crataegi potentiates beta-lactam antibiotics against methicillin-resistant Staphylococcus aureus (MRSA) in vitro and in vivo. Int J Mol Sci. 2013;14(1):1802-21. doi: 10.3390/ ijms14011802.

76. Falci SP, Teixeira MA, Chagas PF, Martinez BB, Loyola $\mathrm{AB}$, Ferreira LM, et al. Antimicrobial activity of Melaleuca sp. oil against clinical isolates of antibiotics resistant Staphylococcus aureus. Acta Cir Bras. 2015;30(6):401-6. doi: 10.1590/s0102-865020150060000005.

77. Razmavar S, Abdulla MA, Ismail SB, Hassandarvish P. Antibacterial activity of leaf extracts of Baeckea frutescens against methicillin-resistant Staphylococcus aureus. Biomed Res Int. 2014;2014:521287. doi: 10.1155/2014/521287.

78. Sianglum W, Srimanote P, Wonglumsom W, Kittiniyom K, Voravuthikunchai SP. Proteome analyses of cellular proteins in methicillin-resistant Staphylococcus aureus treated with rhodomyrtone, a novel antibiotic candidate. PLoS One. 2011;6(2):e16628. doi: 10.1371/journal.pone.0016628.

79. Falodun A, Imieje V, Erharuyi O, Ahomafor J, Jacob MR, Khan SI, et al. Evaluation of three medicinal plant extracts against Plasmodium falciparum and selected microganisms. Afr J Tradit Complement Altern Med. 2014;11(4):142-6.

80. Mustaffa F, Indurkar J, Ismail S, Shah M, Mansor SM. An antimicrobial compound isolated from Cinnamomum iners leaves with activity against methicillin-resistant Staphylococcus aureus. Molecules. 2011;16(4):3037-47. doi: 10.3390/molecules 16043037.

81. Coulibaly K, Zirihi GN, Guessennd-Kouadio N, Oussou KR, Dosso M. Antibacterial properties studies of trunk barks of Terminalia ivorensis, a commercial and medicinal species on some methicillin-resistant Staphylococci species strains. Afr Health Sci. 2014;14(3):753-6. doi: 10.4314/ahs. v14i3.35.

82. Radji M, Agustama RA, Elya B, Tjampakasari CR. Antimicrobial activity of green tea extract against isolates of methicillin-resistant Staphylococcus aureus and multidrug resistant Pseudomonas aeruginosa. Asian Pac J Trop Biomed. 2013;3(8):663-7; discussion 6. doi: 10.1016/s22211691(13)60133-1.

83. Farooqui A, Khan A, Borghetto I, Kazmi SU, Rubino S, Paglietti B. Synergistic antimicrobial activity of Camellia sinensis and Juglans regia against multidrug-resistant bacteria. PLoS One. 2015;10(2):e0118431. doi: 10.1371/ journal.pone.0118431.

84. Chusri S, Voravuthikunchai SP. Damage of staphylococcal cytoplasmic membrane by Quercus infectoria G. Olivier and its components. Lett Appl Microbiol. 2011;52(6):565-72. 
doi: 10.1111/j.1472-765X.2011.03041.x.

85. Chusri S, Voravuthikunchai SP. Detailed studies on Quercus infectoria Olivier (nutgalls) as an alternative treatment for methicillin-resistant Staphylococcus aureus infections. J Appl Microbiol. 2009;106(1):89-96. doi: 10.1111/j.13652672.2008.03979.x.

86. Chusri S, Phatthalung PN, Voravuthikunchai SP. Antibiofilm activity of Quercus infectoria G. Olivier against methicillin-resistant Staphylococcus aureus. Lett Appl Microbiol. 2012;54(6):511-7. doi: 10.1111/j.1472765X.2012.03236.x.

87. Cui Y, Taniguchi S, Kuroda T, Hatano T. Constituents of Psoralea corylifolia fruits and their effects on methicillin-resistant Staphylococcus aureus. Molecules. 2015;20(7):12500-11. doi: 10.3390/molecules200712500.

88. Ifesan BO, Joycharat N, Voravuthikunchai SP. The mode of antistaphylococcal action of Eleutherine americana. FEMS Immunol Med Microbiol. 2009;57(2):193-201. doi: 10.1111/j.1574-695X.2009.00599.x.

89. Karimi E, Jaafar HZ, Ghasemzadeh A, Ebrahimi M. Fatty acid composition, antioxidant and antibacterial properties of the microwave aqueous extract of three varieties of Labisia pumila Benth. Biol Res. 2015;48:9. doi: 10.1186/0717-628748-9.

90. Zucca P, Pintus M, Manzo G, Nieddu M, Steri D, Rinaldi AC. Antimicrobial, antioxidant and anti-tyrosinase properties of extracts of the Mediterranean parasitic plant Cytinus hypocistis. BMC Res Notes. 2015;8:562. doi: 10.1186/s13104-015-1546-5.

91. Yompakdee C, Thunyaharn S, Phaechamud T. Bactericidal Activity of Methanol Extracts of Crabapple Mangrove Tree (Sonneratia caseolaris Linn.) Against Multi-Drug Resistant Pathogens. Indian J Pharm Sci. 2012;74(3):230-6. doi: 10.4103/0250-474x.106065.

92. Coutinho HD, Costa JG, Lima EO, Falcao-Silva VS, Siqueira JP Jr. Herbal therapy associated with antibiotic therapy: potentiation of the antibiotic activity against methicillin--resistant Staphylococcus aureus by Turnera ulmifolia L. BMC Complement Altern Med. 2009;9:13. doi: 10.1186/1472-6882-9-13.

93. de Oliveira FF, Torres AF, Goncalves TB, Santiago GM, de Carvalho CB, Aguiar MB, et al. Efficacy of Plectranthus amboinicus (Lour.) Spreng in a Murine Model of Methicillin-Resistant Staphylococcus aureus Skin Abscesses. Evid Based Complement Alternat Med. 2013;2013:291592. doi: 10.1155/2013/291592.

94. Pesewu GA, Cutler RR, Humber DP. Antibacterial activity of plants used in traditional medicines of Ghana with particular reference to MRSA. J Ethnopharmacol. 2008;116(1):102-11. doi: 10.1016/j.jep.2007.11.005.

95. Al-Qurainy F, AR ZG, Khan S, Nadeem M, Tarroum M, Alaklabi A, et al. Antibacterial activity of leaf extract of Breonadia salicina (Rubiaceae), an endangered medicinal plant of Saudi Arabia. Genet Mol Res. 2013;12(3):3212-9. doi: 10.4238/2013.August.29.5.

96. Pan A, Cauda R, Concia E, Esposito S, Sganga G, Stefani $\mathrm{S}$, et al. Consensus document on controversial issues in the treatment of complicated skin and skin-structure infections. Int J Infect Dis. 2010;14 Suppl 4:S39-53. doi: 10.1016/j.ijid.2010.05.007.

97. Tsao SM, Hsu CC, Yin MC. Garlic extract and two diallyl sulphides inhibit methicillin-resistant Staphylococcus aureus infection in BALB/cA mice. J Antimicrob Chemother. 2003;52(6):974-80. doi: 10.1093/jac/dkg476.

98. Sayed WF, Salem WM, Haridy MA, Hassan NH. Efficacy of Caltropis procera and Ficus sycomorus extracts in treating MRSA (methicillin-resistant Staphylococcus aureus)keratitis in rabbit. EXCLI J. 2015;14:747-57. doi: 10.17179/ excli2015-350.

99. Yamada H, Tateishi M, Harada K, Ohashi T, Shimizu T, Atsumi T, et al. A randomized clinical study of tea catechin inhalation effects on methicillin-resistant Staphylococcus aureus in disabled elderly patients. J Am Med Dir Assoc. 2006;7(2):79-83. doi: 10.1016/j.jamda.2005.06.002.

100. Buenz EJ, Bauer BA, Schnepple DJ, Wahner-Roedler DL, Vandell AG, Howe CL. A randomized Phase I study of Atuna racemosa: a potential new anti-MRSA natural product extract. J Ethnopharmacol. 2007;114(3):371-6. doi: 10.1016/j.jep.2007.08.027.

101. Thompson G, Blackwood B, McMullan R, Alderdice FA, Trinder TJ, Lavery GG, et al. A randomized controlled trial of tea tree oil (5\%) body wash versus standard body wash to prevent colonization with methicillin-resistant Staphylococcus aureus (MRSA) in critically ill adults: research protocol. BMC Infect Dis. 2008;8:161. doi: 10.1186/1471-2334-8-161.

102. Martin KW, Ernst E. Herbal medicines for treatment of bacterial infections: a review of controlled clinical trials. J Antimicrob Chemother. 2003;51(2):241-6.

103. Blackwood B, Thompson G, McMullan R, Stevenson M, Riley TV, Alderdice FA, et al. Tea tree oil (5\%) body wash versus standard care (Johnson's Baby Softwash) to prevent colonization with methicillin-resistant Staphylococcus aureus in critically ill adults: a randomized controlled trial. J Antimicrob Chemother. 2013;68(5):1193-9. doi: 10.1093/ $\mathrm{jac} / \mathrm{dks} 501$. 